\title{
APPLICATION OF REAL TIME PCR AND DNA SEQUENCING FOR DIFFERENTIATION OF FIELD AND VACCINAL STRAINS OF MYCOPLASMA GALLISEPTICUM
}

\author{
AHMED M. ERFAN and AZHAR G. SHALABY \\ Biotechnology unit, Reference Laboratory for Veterinary Quality Control on Poultry Production, Animal Health Research \\ Institute, Nadi El-Seid St., P.O. Box 246, Dokki, Giza 12618, Egypt.
}

Email: azhar_gaber@yahoo.com

Assiut University Email: www.aun.edu.eg

\section{ABSTRACT}

Received at: $1 / 2 / 2015$

Accepted: 18/3/2015
Differentiation between field and vaccinal strains of Mycoplasma gallisepticumis important for the epidemiology of the disease. Real time PCR assay was applied to detect MG and further tested by mgc2 rt-PCR for F, 6/85 and TS-11 strains. Twenty four farms were positive for MG Out of the 50 farms, from which 12 were positive for F strain and 5 were positive for $6 / 85$ strain, while 7 farms were MG positive but negative for live vaccine rt-PCR. DNA nucleotide sequencing for 20 positive cases for $\mathrm{mgc} 2$ gene confirmed the rt-PCR results, some point mutations were found in the isolated strains and grouped the sequenced samples into 4 groups (F, 6/85 and two field strain groups named field group A and B).

Key Words: nucleotide, vaccines of Mycoplasma, rt-PCR, - Sequencing, point mutations

\section{INTRODUCTION}

Mycoplasmas are the smallest known bacteria that are capable of replicating outside cells (Bradbury, 2008). MG infects a wide variety of gallinaceous birds including chickens, turkeys and pheasants (Christensen et al., 1994). Live vaccines that have been used to control $\mathrm{MG}$ include $\mathrm{F}$ strain (Brown et al., 1997), and 6/85 (Evans and Hafeez 1992) and TS-11 (Whithear et al., 1990A). With the widespread use of live vaccines there is an increasing need to differentiate between vaccinal and field strains. Culture methods, are often labour- intensive and requirespecially formulated media, so the improvement of diagnostic tools for direct detection of mycoplasma was necessary (Mekkes and Feberwee 2005). Molecular techniques are cost effective and reliable means of differentiating vaccinal strains from field strains (Collet, 2005). Several techniques have been developed for MG strains differentiation. However, none of these methods have been as widely used as random amplified polymorphic DNA (Charlton et al., 1999). But it has intrinsic problems that affect the reproducibility of the technique (Tyler et al., 1997) thetest also needspure cultures of the target organism (Ferguson 2003). An alternative method should also allow MG strain discrimination at the level of clinical samples so avoiding the MG isolation step that is necessary for RAPD analysis. Nucleotide sequence analysis of a specified gene may allow the development of a PCR that is performed directly on clinical samples to detect MG. Some rtPCR assays were innovated for MG strain differentiation as Taqmanprobes (Ravivet al., 2008). Hybridization probes (Feberwee et al., 2006) or Highresolution melting curve analysis (Ghorashi et al., 2010). Recently, sequencinghave been used for studying the molecular epidemiology of MG (Ferguson et al., 2005). In this study, we tested 2rtPCR assays (MGA0319 and mgc2) in comparison with the mgc2 cPCR. The specificity and sensitivity of the PCR assays were determined. A field study for the surveillance of MG invaccinated and unvaccinated poultry farms was done, and the ability of rt-PCR to differentiate between vaccinal and field strains in the field was evaluated. Finally, sequence analysis of mgc 2 gene of 20 selected positive samples for confirmation of rt-PCR results and for further epidemiological information.

\section{MATERIALS and METHODS}

Samples sources: The field study samples were divided according to vaccination and health status into 4 groups: chickens and turkey flocks vaccinated and unvaccinated diseased or not as described in table no 1 and 2.

We note that 10 tracheal swabs were collected from each flock and lungs just collected from some cases. 
Table 1: Number, species and vaccination status of poultry flocks used in the study.

\begin{tabular}{|c|c|c|c|c|c|}
\hline \multirow{3}{*}{$\begin{array}{l}\text { Species } \\
\text { Chicken }\end{array}$} & \multicolumn{3}{|c|}{$\begin{array}{c}\text { Vaccinated } \\
\text { (Type of vaccine) }\end{array}$} & Unvaccinated & Total \\
\hline & \multicolumn{3}{|c|}{19} & \multirow[t]{3}{*}{19} & \multirow[t]{3}{*}{38} \\
\hline & $\mathrm{F}$ & $6 / 85$ & TS11 & & \\
\hline & 14 & 4 & 1 & & \\
\hline Turkey & \multicolumn{3}{|c|}{5 vaccinated with $6 / 85$} & 7 & 12 \\
\hline Total & \multicolumn{3}{|c|}{24} & 26 & 50 \\
\hline
\end{tabular}

Table 2: Health status of the sampled flocks.

\begin{tabular}{|c|c|c|c|c|c|}
\hline \multirow[t]{2}{*}{ Spp. } & \multicolumn{2}{|c|}{ Diseased } & \multicolumn{2}{|c|}{ Apparently healthy } & \multirow[t]{2}{*}{ Tota } \\
\hline & Vaccinated & Unvaccinated & Vaccinated & Unvaccinated & \\
\hline Chicken & 4 & 10 & 15 & 9 & 38 \\
\hline Turkey & 0 & 3 & 5 & 4 & 12 \\
\hline Total & 4 & 13 & 20 & 13 & 50 \\
\hline
\end{tabular}

The individual samples details types are described in Tables (3) to Table (6).

Table 3: Number and types of samples collected from different types of unvaccinated diseased birds from different sources.

\begin{tabular}{ccccccc}
\hline Code & Species & Age/W & Breed & Town & Govern. & Sample \\
\hline UNVD 1 & Broiler chicken & 5 & Hubbard & Qotoor & Gharbia & 10 T.S \\
\hline UNVD 2 & Broiler chicken & 5 & Hubbard & Sennouris & Faium & 10 T.S \\
\hline UNVD 3 & Broiler chicken & 5 & Hubbard & Kafr El Zayat & Gharbia & 10 T.S \\
\hline UNVD 4 & Broiler turkey & 22 & French & Ashmoun & Menoufia & 10 T.S+4 lung \\
\hline UNVD 5 & Broiler turkey & 22 & Holland & Samalout & Menia & 10 T.S+4 lung \\
\hline UNVD 6 & Broiler chicken & 9 & Sasu & Bepa & Benisuef & $10 \mathrm{~T} . S$ \\
\hline UNVD 7 & Broiler chicken & 6 & Hubbard & Nasser & Benisuef & $10 \mathrm{~T} . S$ \\
\hline UNVD 8 & Broiler chicken & 6 & Kobb & Tela & Menoufia & $10 \mathrm{~T} . S$ \\
\hline UNVD 9 & Broiler chicken & 4 & Baladi & Zagazig & Sharkia & $10 \mathrm{~T} . \mathrm{S}$ \\
\hline UNVD 10 & Broiler chicken & 4 & Sasu & Beyala & Kafr El Sheikh & $10 \mathrm{~T} . S$ \\
\hline UNVD 11 & Broiler chicken & 5 & Cobb & Ayat & Giza & $10 \mathrm{~T} . S$
\end{tabular}


Table 4: Number and types of samples collected from different types of unvaccinated apparently healthy and birds from different sources.

\begin{tabular}{ccccccc}
\hline Code & Breed/spp. & Age/w & Breed & town & Gov. & sample \\
\hline UNVH 1 & Broiler chicken & 4 & Kobb & El Bagour & Menoufia & 10 T.S \\
\hline UNVH 2 & Broiler chicken & 5 & Hubbard & Dsook & Kafr El Sheikh & 10 T.S +4 lung \\
\hline UNVH 3 & Broiler chicken & 5 & Cobb & Ayat & Giza & 10 T.S \\
\hline UNVH 4 & Broiler chicken & 4 & Hubbard & Regwa & $6^{\text {th }}$ October & 10 T.S \\
\hline UNVH 5 & Broiler chicken & 8 & Baladi & Zakazik & Sharkia & 10 T.S \\
\hline UNVH 6 & Broiler chicken & 6 & Hubbard & Regwa & $6^{\text {th }}$ October & 10 T.S \\
\hline UNVH 7 & Broiler chicken & 8 & Sasu & Maghagha & Menia & 10 T.S \\
\hline UNVH 8 & Broiler chicken & 5 & Hubbard & Ashmoun & Menoufia & 20 T.S \\
\hline UNVH 9 & Broiler turkey & 8 & Holland & Benimazar & Menia & 10 T.S+4 lung \\
\hline UNVH 10 & Broiler turkey & 15 & French & Benimazar & Menia & 10 T.S+4 lung \\
\hline UNVH 11 & Broiler turkey & 17 & Holland & Benimazar & Menia & 10 T.S+4 lung \\
\hline UNVH 12 & Broiler chicken & 4 & Hubbard & Kafr El Zayat & Gharbia & 10 T.S \\
\hline UNVH 13 & Broiler turkey & 19 & French & Elkata & $6^{\text {th } \text { October }}$ & 10 T.S \\
\hline
\end{tabular}

Table 5: Number and types of samples collected from different types of vaccinated apparently healthy birds from different sources.

\begin{tabular}{|c|c|c|c|c|c|c|c|}
\hline Code & Species & Age/w & Breed & Town & Govern. & Vacc. & Sample \\
\hline VH 1 & $\begin{array}{l}\text { Layer breeder } \\
\text { chicken }\end{array}$ & 31 & Luhman & Benha & Qalyubia & $6 / 85$ & $10 \mathrm{~T} . \mathrm{S}$ \\
\hline $\mathrm{VH} 2$ & $\begin{array}{c}\text { Broiler breeder } \\
\text { chicken }\end{array}$ & 45 & Buvens & Sadat & Menoufia & $6 / 85$ & $10 \mathrm{~T} . \mathrm{S}$ \\
\hline VH 3 & $\begin{array}{c}\text { Broiler breeder } \\
\text { chicken }\end{array}$ & 39 & Luhman & Tanta & Gharbia & $\mathrm{F}$ & $10 \mathrm{~T} . \mathrm{S}$ \\
\hline VH 4 & Layer chicken & 26 & Luhman & Belbeis & Sharkia & $\mathrm{F}$ & $10 \mathrm{~T} . \mathrm{S}$ \\
\hline VH5 & Broiler turkey & 22 & French & Talkha & Dakahlia & $6 / 85$ & $10 \mathrm{~T} . \mathrm{S}$ \\
\hline VH 6 & Broiler turkey & 20 & French & Met Ghamr & Dakhlia & $6 / 85$ & $10 \mathrm{~T} . \mathrm{S}$ \\
\hline VH 7 & Layer chicken & 32 & Baladi & Kafr El Zayat & Gharbia & $\mathrm{F}$ & $10 \mathrm{~T} . \mathrm{S}$ \\
\hline VH 8 & $\begin{array}{c}\text { Layer breeder } \\
\text { chicken }\end{array}$ & 38 & Hubbard & Wadi El Natroun & Behera & $\mathrm{F}$ & $10 \mathrm{~T} . \mathrm{S}$ \\
\hline VH 9 & $\begin{array}{c}\text { Layer breeder } \\
\text { chicken }\end{array}$ & 40 & Hubbard & Wadi El Natroun & Behera & TS-11 & $10 \mathrm{~T} . \mathrm{S}$ \\
\hline VH 10 & Broiler turkey & 25 & French & Hehia & Sharkia & $6 / 85$ & $10 \mathrm{~T} . \mathrm{S}$ \\
\hline VH 11 & Broiler turkey & 22 & Holland & Mansoura & Dakahlia & $6 / 85$ & $10 \mathrm{~T} . \mathrm{S}$ \\
\hline VH 12 & Layer turkey & 25 & Luhman & Tookh & Qalyubia & $6 / 85$ & $10 \mathrm{~T} . \mathrm{S}$ \\
\hline VH 13 & $\begin{array}{c}\text { Broiler breeder } \\
\text { chicken }\end{array}$ & 22 & Hubbard & Benha & Qalyubia & $\mathrm{F}$ & $10 \mathrm{~T} . \mathrm{S}$ \\
\hline VH 14 & $\begin{array}{c}\text { Layer breeder } \\
\text { chicken }\end{array}$ & 27 & Baladi & Elmahala & Gharbia & $\mathrm{F}$ & $10 \mathrm{~T} . \mathrm{S}$ \\
\hline VH 15 & $\begin{array}{c}\text { Layer breeder } \\
\text { chicken }\end{array}$ & 42 & Baladi & Elshohada & Menoufia & $\bar{F}$ & $10 \mathrm{~T} . \mathrm{S}$ \\
\hline VH 16 & Layer chicken & 22 & Hubbard & Hawamdeya & Giza & $\mathrm{F}$ & $10 \mathrm{~T} . \mathrm{S}$ \\
\hline VH 17 & Layer chicken & 29 & Buvens & Elamrya & Alex & $6 / 85$ & $10 \mathrm{~T} . \mathrm{S}$ \\
\hline VH 18 & Layer chickes & 25 & Baladi & Hehia & Sharkia & $6 / 85$ & 10 T.S \\
\hline VH 19 & Broiler chicken & 19 & French & Talkha & Dakahlia & $\mathrm{F}$ & $10 \mathrm{~T} . \mathrm{S}$ \\
\hline VH 20 & $\begin{array}{c}\text { Layer breeder } \\
\text { chicken }\end{array}$ & 43 & Hubbard & Talkha & Dakahlia & $\bar{F}$ & $10 \mathrm{~T} . \mathrm{S}$ \\
\hline VH 21 & $\begin{array}{c}\text { Layer breeder } \\
\text { chicken }\end{array}$ & $33 \mathrm{w}$ & Buvens & Met Ghamr & Dakhlia & $\mathrm{F}$ & $10 \mathrm{~T} . \mathrm{S}$ \\
\hline VH 22 & $\begin{array}{c}\text { Broiler breeder } \\
\text { chicken }\end{array}$ & $24 \mathrm{w}$ & Hubbard & Talkha & Dakhlia & $\mathrm{F}$ & $10 \mathrm{~T} . \mathrm{S}$ \\
\hline VH 23 & Layer chicken & $65 w$ & Luhman & Talkha & Dakahlia & $\mathrm{F}$ & $10 \mathrm{~T} . \mathrm{S}$ \\
\hline VH24 & Layer chicken & $26 \mathrm{w}$ & Luhman & Belbeis & Sharkia & $\mathrm{F}$ & $10 \mathrm{~T} . \mathrm{S}$ \\
\hline
\end{tabular}


Table 6: Number and types of samples collected from different types of vaccinated diseased birds from different sources.

\begin{tabular}{cccccccc}
\hline Code & Species & Age/w & Breed & Town & Govern. & Vacc & Sample \\
\hline VD 1 & Layer chicken & 36 & Luhman & Kafrshukr & Qalyubia & F & 10 T.S \\
\hline VD 2 & Layer chicken & 16 & Buvens & Kafrshukr & Qalyubia & F & 10 T.S \\
\hline VD 3 & Layer chicken & 24 & Baladi & Abu Kebir & Sharkia & F & 10 T.S \\
\hline VD 4 & Layer chicken & 28 & Baladi & Shebeen Elkanater & Qalyubia & F & 10 T.S \\
\hline
\end{tabular}

Specificity of conventional PCR and rt-PCR: DNA of reference strains were used [MG (R, A5969, HF51, F, 6/85 and TS11), other mycoplasmas (MS, M. meleagridis, $M$. bovis and M.bovigenitalium) and reference bacterial strains (S. aureus, E. coli, $S$. Typhimurium, C. jejuniand $C$. perferingens)].

Detction limits of conventional PCR and rt-PCR: MG cultureswere serially diluted and colony counted according to Rodwell and Whitecomb (1983) Methods for direct and indirect measurement of Mycoplasma growth.] and their counts were $16 \times 10^{4}$, $8 \times 10^{5}$ and $16 \times 10^{5} \mathrm{CFU} / \mathrm{ml}$ for $\mathrm{F}, 6 / 85$ and TS11, respectively.

MG culture: The samples were inoculated in Frey broth and agar medium and incubated at $37^{\circ} \mathrm{C}$. Mycoplasma colonies on agar plates were identified as MG according to OIE (2008).
Conventional PCR and rt-PCR:

DNA purification: DNA was extracted from $200 \mu 1$ of the pooled swabs and grinded lungs using the Qiamp DNA mini kit (Qiagen, Gmbh).

PCR amplification: It was done in a $25 \mu 1$ reaction containing $12.5 \mu \mathrm{l}$ of Quantitect probe rt-PCR buffer (Qiagen, Gmbh), $1 \mu$ l of each primer (20 pmol conc.), $4.5 \mu \mathrm{l}$ of $\mathrm{H}_{2} \mathrm{O}$, and $6 \mu \mathrm{l}$ of template. For rt-PCR, $0.125 \mu \mathrm{l}$ of a $30 \mathrm{pmol}$ probe was added. The cPCR reactions were performed in a Biometra T3 thermal cycler. The cPCR products were separated by electrophoresis on $2 \%$ agarose gel and photographed by a gel documentation system (Alpha Innotech, Biometra). While, rt-PCR was done in a Stratagen MX3005P that was used to amplify DNA and analyze the results using its own software.

Table 7: Oligonucleotide primers and probes sequences encoding for detection of mgc2 MGA0319 gene and gene mgc2 for Strain differentiation of Mycoplasma gallisepticum live vaccines.

\begin{tabular}{|c|c|c|c|}
\hline Primer & Target gene & Primer sequence $\left(5^{\prime}-3^{\prime}\right)$ & $\begin{array}{c}\text { Size of } \\
\text { Amplicon (bp) } \\
\end{array}$ \\
\hline $\mathrm{mgc} 2-\mathrm{F}$ & \multirow{2}{*}{$\begin{array}{c}\text { mgc2 } \\
\text { Garcia } \text { et al., } \\
2004 \\
\end{array}$} & CGCAATTTGGTCCTAATCCCCAACA & \multirow{2}{*}{$300 \mathrm{bp}$} \\
\hline $\operatorname{mgc} 2-\mathrm{R}$ & & TAAACCCACCTCCAGCTTTATTTCC & \\
\hline mglpU26 & \multirow{3}{*}{$\begin{array}{c}\text { MGA0319 } \\
\text { Callison } \text { et al., } \\
2006 \\
\end{array}$} & CTA GAG GGT TGG ACA GTT ATG & \multirow{3}{*}{139 bp } \\
\hline mglp164 & & GCT GCA CTA AAT GAT ACG TCA AA & \\
\hline mglp probe & & 6-FAM-CAG TCA TTA ACA ACT TAC CAC CAG AAT CTG-tamra & \\
\hline mgc2-rt-F & \multirow{3}{*}{$\begin{array}{c}\text { mgc2 rt PCR } \\
\text { Grodioet al., } \\
2008\end{array}$} & GGTCCTAATCCCCAACAAAGAAT & \multirow{3}{*}{$127 \mathrm{bp}$} \\
\hline mgc2-rt-R & & CTTGGTTGGTTCATATTAGGCATTT & \\
\hline mgc2-rt-probe & & 6-FAM CCA CAG GGC TTT GGT GGC CCA-tamra & \\
\hline F strain-for & \multirow{9}{*}{$\begin{array}{c}\text { mgc2 gene } \\
\text { Raviv et al., } \\
2008\end{array}$} & GTT CAA GAA CCA ACT CAA CCA & \multirow{3}{*}{$112 b p$} \\
\hline F strain-rev & & GAT TAA GAC CGA ATT GTG GAT & \\
\hline F strain-probe & & 6-FAM CAA CAA GGA TTT AAT CAA CCT CAG-tamra & \\
\hline TS11-for & & CTC AAG AAC CAA CTC AAC CA & \multirow{3}{*}{$114 \mathrm{bp}$} \\
\hline TS11-rev & & GGG GAT TAG GAA TAA ATT GCG GAT & \\
\hline TS11-probe & & HEX-CAG CCA GGA TTT AAT CAA CCT CAG-Tamra & \\
\hline 6/85-for & & CTC AAG AAC CAA CTC AAC CA-Tamra & \multirow{3}{*}{$112 b p$} \\
\hline 6/85-rev & & GGA TGA GGA CCA AAT TGC GGA T & \\
\hline 6/85-probe & & CY5-CAG CCA GGA TTT AAT CAA CCTCAG-Tamra & \\
\hline
\end{tabular}

DNA sequencing: $\operatorname{mgc} 2$ sequencing for selected 20 positive cases (five $6 / 85$ cases, seven $F$ cases and 8 field cases) were performed. PCR products were purified using QIAquick PCR Product extraction kit. (Qiagen, Valencia). The sequence reaction was done using Bigdye Terminator V3.1 cycle sequencing kit (Perkin-Elmer) and the sequence reaction was purified using Centrisep spin column. DNA sequences were obtained by Applied Biosystems 3130 genetic analyzer (HITACHI, Japan). A phylogenetic tree was created by the Meg Align module of Lasergene DNA Star. 


\section{RESULTS}

Specificity test: MGA0319 and mgc2rt-PCR assays amplified DNA from MG strains only. Also mgc2 cPCR assay yielded specific bands for MG strains only. Also, all of the F, 6/85 and TS-11 rt-PCR assays were specific for its related strains.

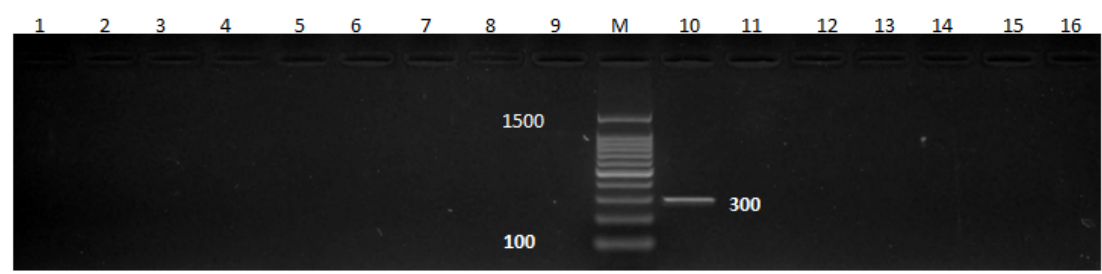

Photo.( 1a ) Gel electrophoresis result of mgc2 gene cPCR specificity test (1st part).

Electrophoresis result of $\mathrm{mgc} 2$ conventional PCR specificity test. No amplification was detected except for the positive control . (1) M. bovigenitalium , (2) S. Typhimurium, (3) C. jejuni, (4) S. aureus, (5) E.coli, (6) C. perferingens, (7) ILT, (M) marker 100 plus , (8) IB , (9) IBD , (10) positive control, (11) AIV, (12) NDV, (13) REO , (14) POX ,(15) Marek's, (16) Negative control

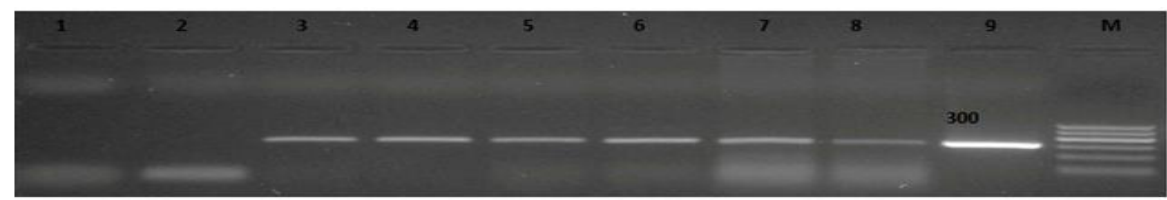

Photo.( (1b) Gel electrophoresis result of mgc2 gene cPCR specificity test (2 $\stackrel{\text { nd }}{\text { part). }}$. Electrophoresis result of $\mathrm{mgc} 2 \mathrm{cPCR}$ specificity test. Positive amplification of $300 \mathrm{bp}$ fragment was detected in MG strains. (L) Ladder $100-600$ bp (1) M. bovis., (2) A5969 strain, (3) HF51 strain, (4) TS11, (5) MG inac, (6) F VAX, (7) $6 / 85$, (8) MS, (9) R strain.

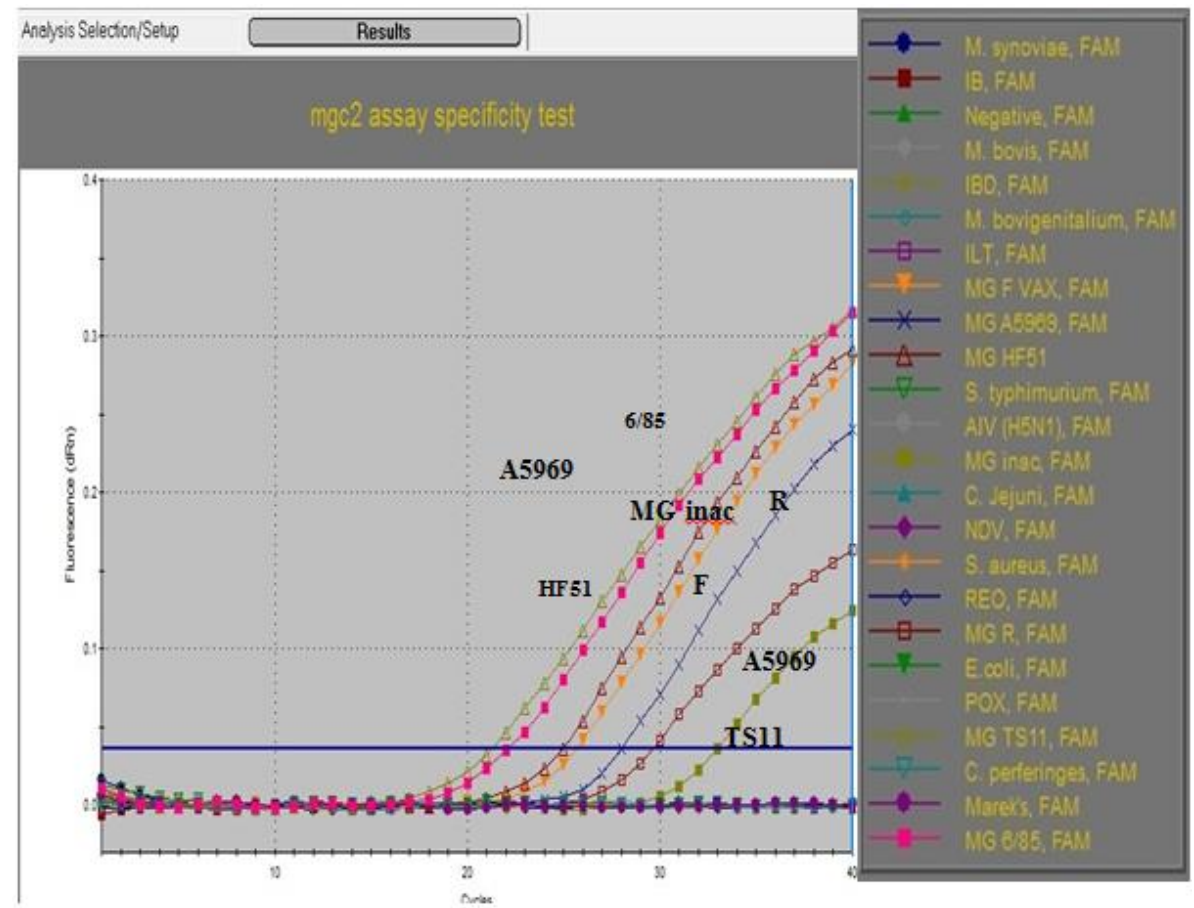

FIG. 1A

Figure (1A \& 1B) Amplification curves of specificity test of the MG (1A mgc2 gene and $1 B$ (MGA0319 gene) rt-PCR assay.

Amplification curves shows positive results for MG strains and negative results for other strains.

Amplification plot generated by StratageneMX3005P software. The fluorescence emission intensity is plotted on the $\mathrm{Y}$ axis versus the cycle number on the $\mathrm{X}$ axis. 


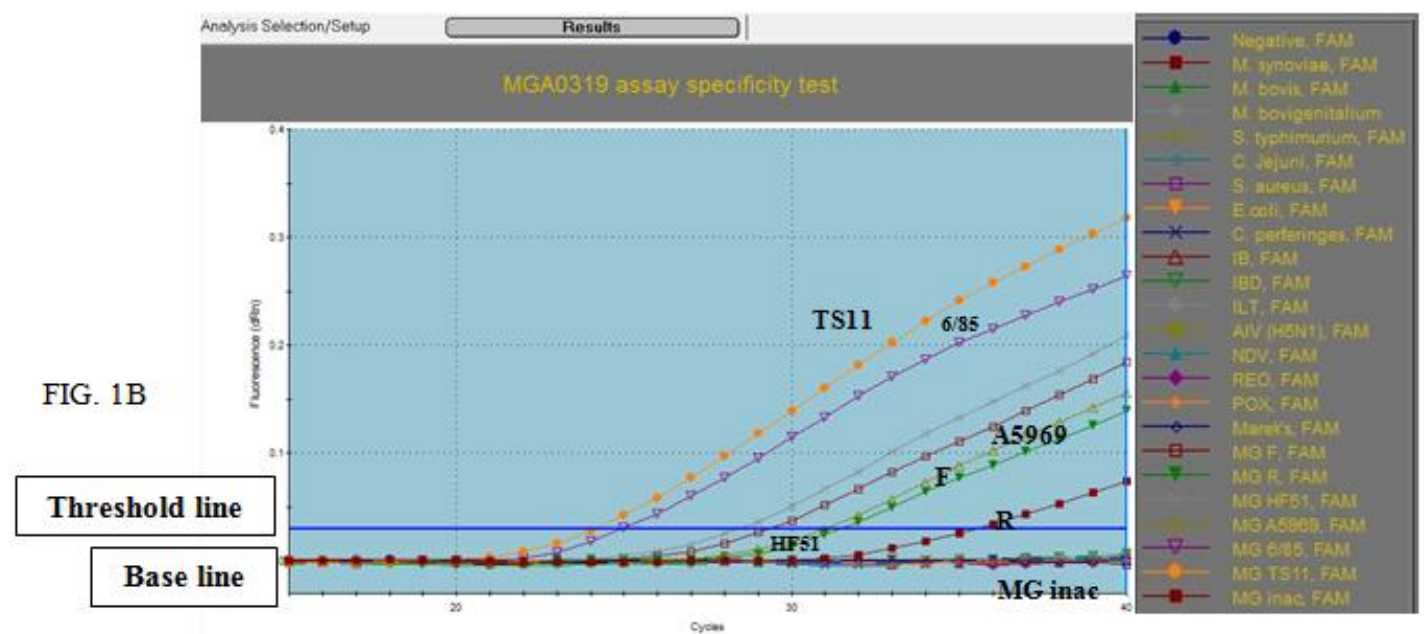

Sensitivity test:

TheMGcPCR and rt-PCR showed variable detection limits, as shown in Table (4).

Table 8: Results of sensitivity test of MG.

\begin{tabular}{ccccccc}
\hline \multirow{2}{*}{ Assay } & \multicolumn{2}{c}{ MG rt-PCR assay } & \multicolumn{2}{c}{ Strain differentiating rt-PCR } & \multirow{2}{*}{ mgc2 cPCR } \\
\cline { 2 - 5 } & $\begin{array}{c}\text { MGA0319 } \\
\text { Gene }\end{array}$ & $\begin{array}{c}\text { mgc2 } \\
\text { gene }\end{array}$ & F & $6 / 85$ & TS-11 & \\
\hline $\begin{array}{c}\text { Detection limit } \\
\text { (CFU / mL) }\end{array}$ & 50 & 14 & 18 & 12 & 20 & 70 \\
\hline
\end{tabular}

Field study results:

Results of different tests for different field groups are shown in table (9).

Table 9: Collective results of all the farms of the field study with different tests.

\begin{tabular}{|c|c|c|c|c|c|c|c|}
\hline \multirow[t]{2}{*}{ Group } & \multirow[t]{2}{*}{ Isolation } & \multirow{2}{*}{$\begin{array}{l}\text { mgc2 } \\
\text { cPCR }\end{array}$} & \multirow{2}{*}{$\begin{array}{l}\text { MGA0319 } \\
\text { rt-PCR }\end{array}$} & \multirow{2}{*}{$\begin{array}{c}\text { mgc2 } \\
\text { rt-PCR }\end{array}$} & \multicolumn{3}{|c|}{ Live vaccine rt-PCR } \\
\hline & & & & & $\mathbf{F}$ & $6 / 85$ & TS-11 \\
\hline VH & $5 / 20$ & $6 / 20$ & $6 / 20$ & $10 / 20$ & $5 / 10 / 20$ & $5 / 10 / 20$ & $0 / 10 / 20$ \\
\hline UNVH & $0 / 13$ & $2 / 13$ & $4 / 13$ & $4 / 13$ & $4 / 4 / 13$ & $0 / 4 / 13$ & $0 / 4 / 13$ \\
\hline VD & $2 / 4$ & $3 / 4$ & $3 / 4$ & $2 / 4$ & $2 / 2 / 4$ & $0 / 2 / 4$ & $0 / 2 / 4$ \\
\hline UNVD & $3 / 13$ & $4 / 13$ & $7 / 13$ & $8 / 13$ & $1 / 8 / 13$ & $0 / 8 / 13$ & $0 / 7 / 13$ \\
\hline $\begin{array}{c}\text { Total } \\
\text { positive }\end{array}$ & $\begin{array}{l}10 / 50 \\
(20 \%)\end{array}$ & $\begin{array}{l}15 / 50 \\
(30 \%)\end{array}$ & $\begin{array}{c}20 / 50 \\
(40 \%)\end{array}$ & $\begin{array}{l}24 / 50 \\
(48 \%)\end{array}$ & $\begin{array}{l}12 / 50 \\
(24 \%)\end{array}$ & $\begin{array}{c}5 / 50 \\
(10 \%)\end{array}$ & $\begin{array}{c}0 / 50 \\
(0)\end{array}$ \\
\hline \multicolumn{5}{|c|}{$\%$ in relation to MG positive cases } & $\begin{array}{l}12 / 24 \\
(50 \%)\end{array}$ & $\begin{array}{c}5 / 24 \\
(16.67 \%)\end{array}$ & $\begin{array}{c}0 / 24 \\
(0)\end{array}$ \\
\hline
\end{tabular}

VH: vaccinated healthy group UNVH: unvaccinated healthy group VD: vaccinated diseased UNVD: unvaccinated diseased group

Also, the results of different tests in relation to the birds' health statuses are shown in table (10).

Table 10: Results of the field study with different PCR tests in relation to health status of the birds.

\begin{tabular}{ccccccccc}
\hline \multirow{2}{*}{$\begin{array}{c}\text { Health } \\
\text { status }\end{array}$} & Isolation & mgc2 cPCR & MGA0319 & mgc2 rt- & \multicolumn{3}{c}{ Live vaccine rt-PCR } \\
\cline { 6 - 8 } & & & rt-PCR & PCR & F & $\mathbf{6 / 8 5}$ & TS-11 \\
\hline Healthy & $5 / 33$ & $8 / 33$ & $10 / 33$ & $14 / 33$ & $9 / 14 / 33$ & $5 / 14 / 33$ & $0 / 14 / 33$ \\
& $(15.15 \%)$ & $(24.50 \%)$ & $(30.3 \%)$ & $(42.50 \%)$ & $(64.28 \%)^{\mathrm{a}}$ & $(35.7 \%)^{\mathrm{a}}$ & 0 & 0 \\
\hline Diseased & $5 / 17$ & $7 / 17$ & $10 / 17$ & & $10 / 17$ & $3 / 10 / 17$ & $0 / 10 / 17$ & $0 / 10 / 17$ \\
& $(29.4 \%)$ & $(41.20 \%)$ & $(58.80 \%)$ & $(58.80 \%)$ & $(40 \%)^{\mathrm{a}}$ & 0 & 0 \\
& & & & & $(23.52 \%)^{\mathrm{b}}$ & 0 & 0 \\
\hline
\end{tabular}

a: Percent in relation to MG positive cases only

b: Percent in relation to all farms 
DNA sequencing results:

4 out of the 5 positive 6/85 samples: Healthy cases VH1, VH5, VH17 and VH18 (Accession no.JX981926, JX981928, JX981929 and JX981930, respectively) showed $100 \%$ identity and query coverage to 6/85 strain (AY556231.1). However, one sample Healthy VH2 (JX981927) showed 100\% identity and $99 \%$ query coverage as it had a mutation from thymine to adenine (Position 243) which changed the $\mathrm{N}$ (Asparagine) amino acid to $\mathrm{K}$ (Lysine) causing a missense non conservative mutation.

Six positive $F$ strain samples VH4, VD3, VD4, UNVD2, UNVD9 and UNVH4 (Acc. No.JX981931, JX981934，JX981935，JX981936，JX981937 and JX981933, respectively) showed100\% identity to F strain (CP001873.1), while one sample VH20 (JX981932) had 99\% identity as it had a silent mutation due to a nucleotide change from thymine to cytosine.
The DNA sequence grouped the 8 field strains samples into 2 groups. The $1^{\text {st }}$ one called Field group A included 5 samples UNVD6, UNVD7, UNVD12, UNVD13 and UNVH12 (Acc. No. JX981939, JX981940, JX981941, JX981942 and JX981938, respectively) that showed great relation to some Egyptian strains as Eis6-T-10 (HQ591357.1) and some Israelian strains as UHP1 (AY556297.1) and YBS2 (AY556298.1).

The $2^{\text {nd }}$ group was called Field group $\mathrm{B}$, which included 2 identical samples UNVD3 (JX981943) and UNVD4 (JX981944) and another variant sample UNVD8 (JX981945). All of the group B strains showed great relation to the Pakistanian strain EgPK10AP08 (FJ395202.1), the Egyptian strain EGY/67240/CK08 (HQ143372.1) and S6 (AY556229.1). However, there was a mutation from the Pakistanian strain in 1 position in all samples (Position 36) that has lead to a mutation from I (Isoleucine) to $\mathrm{M}$ (Methionine) and another 3 silent mutations in the variant sample (JX981945).

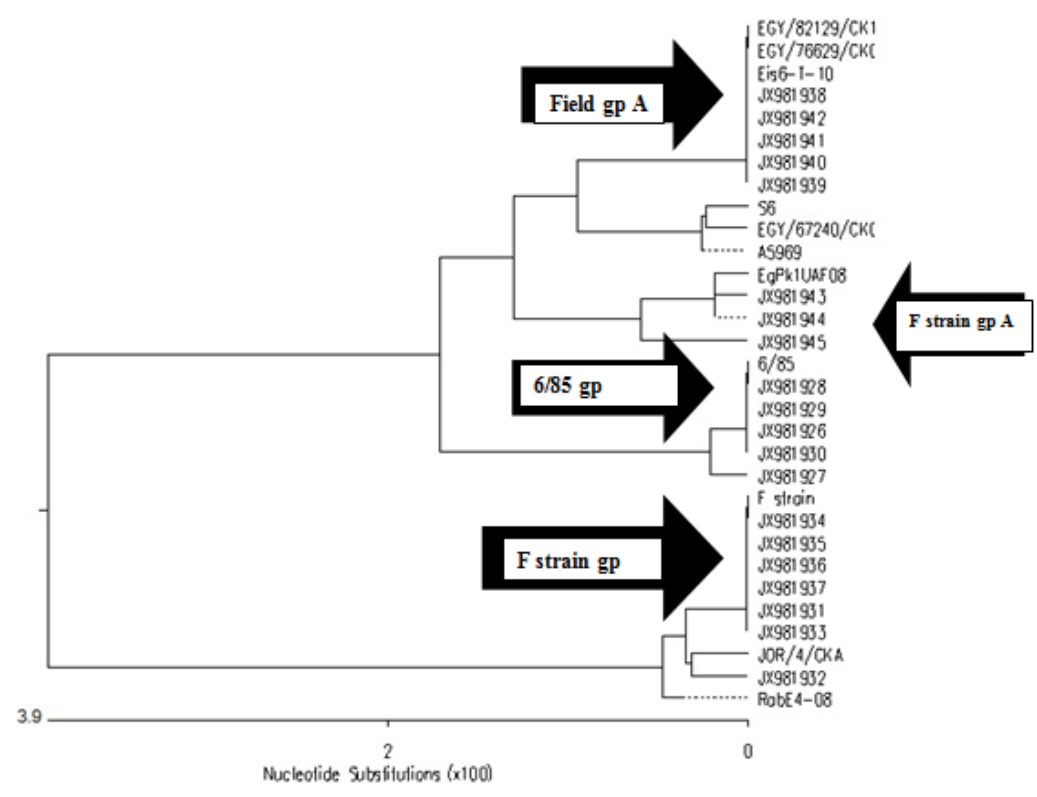

Fig. 1: phylogenetic tree of all field study samples.

\section{DISCUSSION}

The present study results showed that cPCR was more sensitive than isolation. This result agreed with Kempf et al. (1993); Saif-Edin, (1997); El Shater and Oraby, (2001) as their results showed that cPCR was more sensitive than isolation in different samples. The present study showed that rt-PCR yielded 20 and 24 positive samples for $\mathrm{mgc} 2$ and MGA0319 assays, while cPCR showed only 15 positive samples. The two tests agreed with each otherin $94.04 \%$ of samples. And both of the rt-PCR assays were sensitive than the cPCR assays. These results confirmed the results obtained in the sensitivity test of the validation step, this could be due to the determination of the CT value within the logarithmic phase of the amplification reaction, instead of the end point determination used by conventional systems, also detection of result by a computerized system in rt-PCR is much better than visual detection of bands in cPCR. The present study results differed from that of Callison et al. (2006) as they found that MGLP and cPCR assays had similar results for detection of MG. However, it agreed with Mekkes and Febrewee 
(2005), who found that the rt-PCR detection limit was 10 to 1000 times lower than that of cPCR.

The specificity test showed that themgc2 rt-PCR, MGA0319 rt-PCR assays and the mgc2 cPCR were specific for MG strains. This was consistent with that obtained by Garcia et al. (2004); Callison et al. (2006); Grodio et al. (2008) who have tested these assays respectively and had similar results. Also our results agreed with those of Raviv et al. (2008) who found similar results for the live vaccinal strain assays. Also the result of the current study concerning the relation between the results of $\mathrm{mgc} 2 \mathrm{cPCR}$ and MGA0319 rt-PCR in the field study was close to that found by Callison et al. (2006) who found the agreement between the two tests was $97.74 \%$, while it was $96.42 \%$ in our study. The mgc 2 rt-PCR assay showed a detection limit of $14 \mathrm{CFU} / \mathrm{ml}$, this result was close to that of Grodio et al. (2008), who found it less than 10 copies per reaction when tested with MG DNA. The MGA0319 rt-PCR $50 \mathrm{CFU} / \mathrm{ml}$ detection limit was also close to that of Callison et al. (2006) who reached the 25 copies detection limit. The $\mathrm{mgc} 2$ cPCR sensitivity test resulted in the study done by Garcia et al. (2004) was 40 CCU/reaction which can't be compared with our's because of the different unit. The detection limits for $6 / 85, \mathrm{~F}$, TS-11 assays were 12, 18 and $20 \mathrm{CFU} / \mathrm{ml}$, respectively. These limits were also so close to that reached by Raviv et al. (2008) who found the detection limits about 10 copies/reaction. From our antimortum findings, some cases in our study had severe respiratory signs, but it showed weak positive result in mgc2 and MGA0319 rt-PCR. This was described by Carli and Eyigor (2003), who found that the swabs taken by scraping trachea of necropsied birds are much better than live chicken swabs. This explains the negative results of the vaccinated birds like cases VD1, The strong positive rt-PCR results for some cases in which we could collect lung samples like UNVD2 confirmed this idea. Also, the negative results shown by the vaccinated flocks like VD1 may be due to vaccination failure. Case UNVD 13 was also positive for MG and negative by isolation. This result may agree with the idea of Ley and Yoder (1997) who reported that MG infections in turkeys resulting in mild clinical disease are unusual, While this result disagreed with Kempf et al. (1997) who stated that mild or subclinical cases of MG can be observed naturally and experimentally in chickens and turkeys.

Although some cases as UNVD 1 and UNVD 3 were collected from diseased flocks, they were $\mathrm{MG}$ negative which may be due to infection with other respiratory microorganisms. Furthermore, cases like UNVH4 and UNVD9 were unvaccinated but they were F strain positive. This was explained by Kleven (2002), who stated the possible vertical and lateral transmission of F strain within or between farms.
The mgc2 gene was the target for DNA sequencing as itwas characterized by the presence of different nucleotide insertions/deletions, which may be helpful for strains differentiation. While, the MGA_0319 gene encodes a predicted conserved surface lipoprotein (Ferguson et al., 2005). The 6/85 VH2 DNA sequence was closely related to the MG TLS-2 strain (JN113387.1), this strain was isolated from Israelian broiler breeder farm and was sensitive to tylosin, tilmicosin and enrofloxacin as reported by Gerchman et al. (2011) this may confirm that this mutation didn't increase the virulence. This was explained by Steinage et al. (2003) who reported that $6 / 85$-like isolates was recovered from vaccinated and unvaccinated contact chickens long after vaccination. And also agreed with Zaki et al. (2004) who studied the safety of MG 6/85 vaccine after backpassage in turkeys and found that both the original and the back passaged strains were apathogenic in turkeys.

Silentmutation in the F strain sample VH20 can be an explanation for the apparently healthy state found in this farm. But this mutation lead to sub grouping of VH20 in another subgroup that contained the Jordanian strain JOR/4/CKA (HQ143378.1), which was reported as F strain by Gharaibeh et al. (2011) who found that it was indistinguishable from $F$ strain by RAPD and IGSR sequencing. The 5 field group A samples showed $100 \%$ identity with the Egyptian field strains Eis6-T-10, which was isolated from turkey farm and had an identity around 94-99\% to Israelian strains as reported by Eissa et al. (2011). The phylogenetic tree showed that the field group A samples were also related to some geographically related field strains as the Israelian chicken strain (UHP1) and turkey strains YBS2. The field group A strains had different pathogenic profile as it didn't cause symptoms in case UNVH12. However, this may be related to the dose and time of infection in relation to time of sampling. The field group B samples were related to many field strains, but the most related one was the Pakistanian strain EgPK10AP08, which was isolated from a 22w layer farm, which showed rales, sinusitis and was related to S6, A5969. The field group B samples were also related to some Egyptian field strains as EGY/67240/CK08 (HQ143372.1). Collectively, the mgc2 DNA sequence was able to divide the 20 sequenced samples into the 4 mentioned groups. It was helpful to confirm the results of the live vaccine rt-PCR assays, and also to detect mutations within these vaccinal strains, also to give an image about some of the field strains that are circulating in the Egyptian chicken and turkey farms. The results showed that rt-PCR was valuable to differentiate live vaccinal strains. However, there were some point mutations in the vaccinal strains $6 / 85$ and $F$ strain which didn't lead to the rise of higher virulent strains, and also the rt-PCR assays were still able to detect these vaccinal strains. While, the detection of these 
mutations will not be done by rt-PCR unless repeated in many strains and lead to the development of rtPCR assay to detect these mutations. The same idea can be applied for the field strains after collection of data from different studies that can help to design new field strain rt-PCR assays. Continuing the studies related to this idea will help to make a database about the Egyptian MG state, which may help to assess the immune protection efficiency of the current, used MGvaccines, and may also lead to the creation of new homologous or heterologous vaccines for the Egyptian field.

\section{REFERENCES}

Bradbury, J.M. (2008): The Mycoplasma "a wolf in sheep's clothing. Department of veterinary pathology 14: 36-37. University of Liver pool proceeding of the $24^{\text {th }}$ technical conference.

Brown, J.E.; Branton, S.L. and May, J.D. (1997): Epitope diversity of $F$ strain Mycoplasmagallisepticum detected by flow cytometry. Avian Dis., 41: 289-295.

Callison, S.A.; Ribet, S.M.; Sun, S.; Ikuta, N.; Hilt, D.; Leiting, V.; Kleven, S.H.; Suarez, D.L. and Garcia, M. (2006): Development and validation of Real- Time Taqmqn polymerase chain reaction assay for the detection of Mycoplasmagallisepticum in Naturally infected birds. Avi Dis., 50: 537- 544.

Carli, K.T. and Eyigor, A. (2003): Real time polymerase chain reaction for detection of Mycoplasmagallisepticum in chicken trachea. Avian diseases., 47: 712- 717.

Charlton, B.R.; Bickford, A.A.; Walker, R.L. and Yamamoto. R. (1999): Complementary randomly amplified polymorphic DNA (RAPD) analysis patterns and primer sets to differentiate Mycoplasma gallisepticum strains. J. Vet. Diag. Invest. 11: 158-61.

Christensen, N.H.; Christine, A.; Yavari, A.J. Mcbain and Bradbury, J.M. (1994): Investigation into survival of M.gallisepticum. M. synoviae and $M$. Iowaeon materials found in the poultry house environment. Avainpathol., 23: 127-143.

Collet, S.R. (2005): Monitoring broiler breeder flocks for Mycoplasmagallisepticum after vaccination with ts11. MVScthesis. University of Pretoria etd.

Eissa, S.I.; Hassan, A.M.; Metwally, A.M.; Hashem, Y.M. and Abd El-Aziz, E.E. (2011): Molecular characterization of Mycoplasma gallisepticum isolated from chicken and turkey. $11^{\text {th }}$ Scientific conference ( $3^{\text {rd }}$ International) Cairo University.

El- Shater, S.A.A. and Oraby, F.A.I. (2001): Incidence of Mycoplasma infection. In Ph.D. Thesis, Assiut University.
Evans, R.D. and Haffez, Y.S. (1992): Evaluation of a Mycoplasma gallisepticum strain exhibiting reduced virulence for prevention and control of poultry mycoplasmosis. Avian Dis. 36: 197-201.

Feberwee, A.; Landman, W.J.M.; VonBannishet TWysmullera, Th.; Klinkenberg, D.; Vernooij, J.C.M.; Gielkens, A.L.J. and Stegeman, J.A. (2006): The effect of a live vaccine on the horizontal transmission of Mycoplasma gallisepticum. Avian pathology 35(5): 359-366.

Ferguson, N.M. (2003): The evaluation of a live Mycoplasma gallisepticum vaccine candidate and DNA sequence analysis in the molecular epidemiology of Mycoplasma gallisepticum. (Phd thesis, The University of Georgia).

Ferguson, N.M.; Hepp, D.; Sun, S.; IkutaA, N.; Levisohn, S.; Kleven, S.H. and Garcia, M. (2005): Use of molecular diversity of Mycoplasma gallisepticum by gene-targeted sequencing (GTS) and random amplified polymorphic DNA (RAPD) analysis for epidemiological studies. Microbiology, 151: 1883-1893.

Garcia, M.; Ikuta, N.; Levisohn, S. and Kleven, S.H. (2004): Evaluation and comparison of various PCR methods for detetion of Mycoplasmagallisepticum infection in chickens. Avian Dis., 49: 125-132.

Gerchman, I.; Levisohn, S.; Mikula, I.; Manso-Silvan, L. and Lynsyansky, I. (2011): Characterization of in vivo-acquired resistance to macrolides of Mycoplasma gallisepticum strains isolated from poultry. Veterinary Research 2011, 42:90.

Gharaibeh, S.; Laibinis, V.; Wooten, R.; Stabler, L. and Ferguson, N.N. (2011): Molecular Characterization of Mycoplasma gallisepticum Isolates from Jordan. Avi. Dis. 55: 212-216.

Ghorashi, S.A.; Noormohammadi, A.H. and Markham, P.F. (2010): Differentiation of Mycoplasma gallisepticum strain using PCR and high-resolution melting curve analysis. Microbiology, 156: 1019-1029.

Grodio, J.L.; Dhondt, K.V.; Connell, P.H.O. and Schat. K.A. (2008): Detection and quantification of Mycoplasma gallisepticum genome load in conjunctival samples of experimentally infected house finches (Carpodacusmexicanus) using real-time polymerase chain reaction. Avian pathology. 37(4): 385-391.

Kempf, I.; Blanchard, A.; Gesbert, F.; Guittet, M. and Bennejean, G. (1993): The polymerase chain reaction for $M$. gallisepticumdetection. Avian Pathol.22: 739- 750 .

Kempf, I.; Gesbert, F. and Guittet, M. (1997): Experimental infection of chickens with an atypical Mycoplasma gallisepticumstrain., 
comparison of diagnostic methods. Vet. Sci. 63: 211-213.

Kleven, S.H. (2002): Recent developments in Mycoplasma diagnosis and control. Proceedings of the Western Poultry Disease Conference, 51: 109-113.

Ley, D.H. and Yoder, H.W.Jr. (1997): Mycoplasma gallisepticum infection. In: Diseases of Poultry, 9th ed. B. W. Calnek, H.J. Barnes, C. W. Beard, L.R. McDougald, and Y.M. Saif, eds. Iowa State University Press, Ames, Iowa. pp. 194-207.

Mekkes, D.R. and Feberwee, A. (2005): Real- Time polymerase chain reaction for the qualitative and Quantitative detection of Mycoplasmagallisepticum. Avian Path., 34(4): 348-354.

OIE (2008): AvainMycoplasmosis in Manual of diagnostic tests and vaccines for terrasterialanimals. Section 2.2.Aves (chapter 2.3.5).

Raviv, Z.; Callison, S.A.; Noel, N.F. and Kleven, S.H. (2008): Strain differentiating real-time PCR for Mycoplasmagallisepticum live vaccine evaluation studies. Vet. Microbiol. 129: 179-189.

Rodwell, A.W. and Whitecomb, R.F. (1983): Methods for direct and indirect measurement of Mycoplasma growth. In "Methods in
Mycoplasology" (Razin, S. and Tully, J.G. eds.) 1: 127-135. Academic press, New York.

Saif- Edin, M. (1997): Situation of Mycoplasma infections among chickens in Upper Egypt with evaluation of Different diagnostic techniques. Assuit Vet. Med. J. 37(73).

Steinlage, S.J.T.; Ferguson, N.; Sander, J.E.; Garica, M.; Subramanian, S.; Leiting, V.A. and Kleven, S.H. (2003): Isolation and Characterization of a 6/85-like Mycoplasma gallisepticum from Commercial Laying Hens. Avian Dis. 47: 499-505.

Tyler, K.D.; Wang, G.; Tyler, S.D. and Johnson, W.M. (1997): Factors affecting the reliability and reproducibility of amplification based DNA fingerprinting of representative bacterial pathogens. J. Clin. Microbiol., 35(2): 339-346.

Whithear, K.G.; Soeripto, K.G.; Harrigan, K.E. and Ghiocas, E. (1990a): Immunogenicity of a temperature sensitive mutant Mycoplasma gallisepticumvaccine. Aust. Vet. J. 67: 168-174.

Whithear, K.G.; Soeripto, K.G.; Harrigan, K.E. and Ghiocas, E. $(1990$ b): Safety of temperature sensitive mutant Mycoplasma gallisepticum vaccine. Assiut. Vet. J. 67:159-165.

Zaki, M.M.; Ferguson, N.; Leiting, V. and Kleven, S.H. (2004): Safety of Mycoplasma gallisepticum $6 / 85$ vaccine strain after age in turkeys. Avian Dis. 48: 642-646.

\section{استخدام تفاعل انزيم البلمرة المتسلسل فى الوقت الحقيقى وإختبار الكثف عن التتابع النيكلوتيدى للتمييز

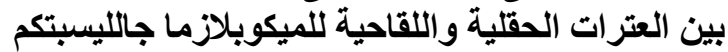

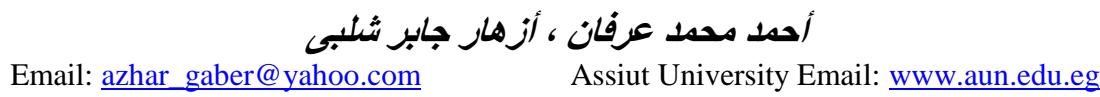

التمبيز بين العترات الحقلية واللقاحية للميكوبلازما جاليسبتكم هام لمعرفة وبائية المرض. في هذه الدراسة تم استخدام إختبار تفاعل

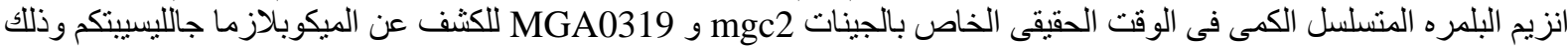

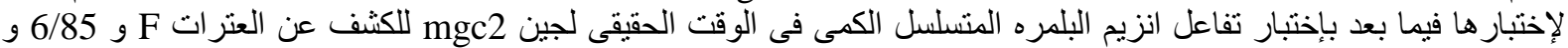

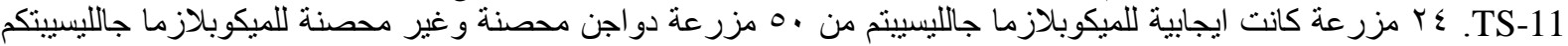

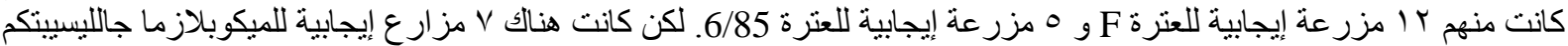

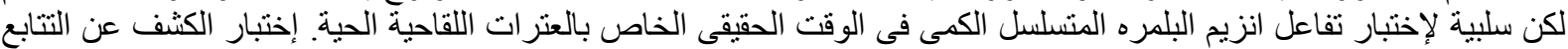

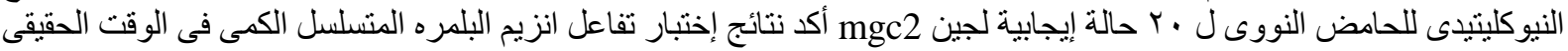

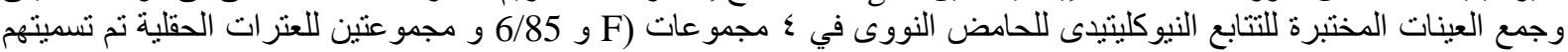
مجموعة حقلية أو ب).

(الكلمات الدالة: نيوكليوتيدات_ لقاحات ميكوبلازما ـ البلمرة المتسلسلـ التحليل الجينىـ طفرات) 